\title{
Pediatrik yanık yaralanmalarında aile yükünü etkileyen faktörlerin incelenmesi
}

\author{
Özden ÖZKAL¹, Damlagül AYDIN ÖZCAN², Güllü AYDIN², Semra TOPUZ², Ali KONAN
}

\begin{abstract}
Amaç: Pediatrik yanıklarda, uzayan tedavi süreçleri bakım veren rolünü üstlenen anneler için psikososyal açıdan zorlayıcı olabilmektedir. Bu çalışmanın amacı pediatrik yanık yaralanmalarında aile yükünü etkileyen faktörleri araştırmaktı.

Yöntem: Bu çalışmaya 32 (18K/14E) yanık yaralanması olan çocuk ve anneleri dahil edildi. Çocukların ve annelerin demografik bilgileri ve yanık yaralanmasına ilișkin veriler kaydedildi. Çocuğun aileye olan yükü Aile Etki Ölçeği ile, annelerin kaygı düzeyleri Durumluk Sürekli Kaygı Ölçeği ile, çocukların yaralanma bölgesinde oluşan hipertrofik skar kalitesi Hasta ve Gözlemci Skar Değerlendirme Ölçeği ile, eklemlerin hareket açıklığı ise gonyometre ile değerlendirildi.

Bulgular: Çoklu doğrusal regresyon analiz sonuçlarına göre, annenin kaygı düzeyinin, hipertrofik skarın kalitesinin, bası giysisi varlığının, yaralanma sonrası geçen sürenin, toplam yanık yüzey alanının (TYY), herhangi bir eklemin/üst ekstremite ekleminin eklem hareket açıkığında limitasyon olmasının ve cerrahi sayısının Aile Etki Ölçeği için anlamlı belirleyicileri olduğu bulundu $(p<0,05)$.
\end{abstract}

Sonuç: Annenin yüksek kaygı düzeyine sahip olması, kötüleşmiş hipertrofik skar kalitesi, tedavide bası giysisi kullanımı, eklemlerde limitasyon varlı̆̆ı ve yanık sonrası geçen süredeki, cerrahi sayısındaki ve TYYA'ndaki artış çocuğun aileye olan yükünü artırmaktadır. Yanık tedavi uygulamalarında, çocuk ve aile bütüncül değerlendirilerek yanık öyküsünün aileye olan yükünü azaltacak yaklaşımlar seçilmesi önerilir.

Anahtar kelimeler: Yanıklar, Skarlar, Pediatri, Anksiyete, Aile.

Investigation of the factors affecting family burden in pediatric burn injuries

Purpose: In pediatric burns, prolonged treatment processes can be psychosocially challenging for mothers who take the role of caregivers. The aim of this study was to investigate the factors affecting family burden in pediatric burn injuries.

Methods: Thirty-two (18F/14M) children with burn injuries and their mothers were included in this study. The demographic data of the children and mothers and the data regarding burn injury were recorded. The burden of the child on family, anxiety levels of the mothers, hypertrophic scar quality and the range of motion (ROM) at the joints were evaluated with the Family Impact Scale (FIS), State Trait Anxiety Scale, Patient and Observer Scar Assessment Scale and a goniometer, respectively.

Results: According to multiple linear regression analysis results, mothers 'anxiety level, quality of hypertrophic scar, presence of pressure garment, time since injury, total burn surface area (TBSA), limitation in any of the joint/upper limb joint ROMs and number of operations were found to be significant determinants for FIS $(p<0.05)$.

Conclusion: The mother's high anxiety level, poor hypertrophic scar quality, the use of compression garments in the treatment, presence of limitation in the joints and increase in the time since injury, number of surgeries, and the TBSA increase the burden of the child on family. In burn treatment practices, it is recommended to choose approaches that will reduce the burden of the burn history on the family by evaluating the child and family as a holistic approach.

Keywords: Burns, Scars, Pediatrics, Anxiety, Family.

1: Bursa Uludağ University, Faculty of Health Sciences, Department of Physiotherapy and Rehabilitation, Bursa, Turkey

2: Hacettepe University, Faculty of Physical Therapy and Rehabilitation, Ankara, Turkey

3: Hacettepe University, School of Medicine, Department of General Surgery, Ankara, Turkey

Corresponding Author: Özden Özkal: ozdenozkal@gmail.com

ORCID IDs (order of authors): 0000-0002-8826-9930; 0000-0001-6026-0144; 0000-0003-1658-7697; 0000-0002-9090-3937;

0000-0001-8470-6534

Received: February 24, 2021. Accepted: May 16, 2021 
$\mathrm{Y}$ anık yaralanması bir çocuğun veya ergenin deneyimleyebileceği en travmatik olaylardan birisi olup, ağır yanık yaralanmaları yaşamı tehdit eden ciddi sonuçlar oluş̧turabilir. ${ }^{1}$ Yaralanma sonrası en önemli akut yanıtlardan biri olan ağrı uzamış hastane içi tedavi süreci ile birleştiğinde, yanık öyküsü hem çocuk hem de aile için travmatik bir deneyime dönüşebilir. ${ }^{2}$ Uzamış tedavi sürecine ek olarak, çok sayıda cerrahi operasyon geçirilmesi, stresli rehabilitasyon dönemi pediatrik hasta ile beraber ailenin de yaşamını olumsuz yönde etkiler. ${ }^{3}$

Literatürde yanık yaralanması olan pediatrik bireylerin ailelerinin kayg ve depresyon düzeylerinin veya posttravmatik stres bozukluğu semptomlarının değerlendirildiği araştırmalar mevcuttur. ${ }^{1,2,4,5}$ McGarry vd. yaptıkları araştırmada çocukların yanık öykülerini takiben ailelerin ciddi psikolojik sıkıntılar yaşadığını, genel popülasyona kıyasla yüksek kaygı ve depresyon düzeyine sahip olduklarını bildirmişlerdir. ${ }^{2}$ Sveen vd. ise yanığın şiddetinin hem çocuğun hem de ailenin algiladığ psikososyal stres düzeyi ile ilişkili olduğunu göstermişlerdir. ${ }^{1}$ Buna ek olarak, yanık yaralanması olan çocuk fiziksel fonksiyonları açısından iyileşmiş olsa bile, ailenin kayg, stres gibi duygu durumundaki etkilenimlerin bazı durumlarda yeniden ortaya çıkabildiği belirtilmiştir. ${ }^{1}$ Ailelerin yanık yaralanması sonrası uzun dönem tedavide rollerinin araştırıldığı bir nitel analiz çalışmasında ise, özellikle skar doku tedavisinde, bası giysisi kullanımı ile birlikte annenin bir bakım veren olarak aile içindeki rolünün değiştiği ve yükünün $\operatorname{arttığı~}$ vurgulanmıştır. ${ }^{3}$

Mevcut çalışmalarda ${ }^{2,3,5}$ çocuktaki yanık varlığının aile içinde özellikle annenin rolünü etkilediği gösterilmiş olmasına rağmen, yanığın aile üzerindeki yükünü ve bu yükü etkileyen etmenlerin neler olduğunu araştıran bir çalışma bulunmamaktadır. Aile yükünü etkileyen faktörlerin ortaya konması, annenin yanık yaralanması olan çocuğunun uzun dönem rehabilitasyonunda üstleneceği bakım veren rolünde ve bu tedavi sürecinde yaşanacak olası zorlukların öngörülmesine ve yönetilmesine olanak sağlayacaktır. Bu çalışmanın amacı, yanık yaralanması olan çocuğun aileye olan yükünü etkileyen faktörleri araştırmaktır.

\section{YÖNTEM}

$\mathrm{Bu}$ Çalışma Hacettepe Üniversitesi Hastanesi Yanık Ünitesi'nde Ocak 2019-Ocak 2020 tarihleri arasında prospektif olarak gerçekleştirildi. Araştırmaya katılmayı kabul eden annelere yapılacak değerlendirmeler hakkında bilgi verilerek hem annelerden hem de okur yazarlığ onamları alındı. Çalışma için Hacettepe Üniversitesi Girişimsel Olmayan Etik Kurulu'ndan onay alındı (GO 19/28-08.01.2019).

Katılımcllar

Araştırmaya 2-17 yaş aralığında yanık yaralanması olan pediatrik hastalar ve çocuğun evdeki bakımıyla birebir ilgilenen anneleri dahil edildi. Çalışmaya Türkçe okuma ve yazma bilen, çocuğu ayaktan veya yatarak Hacettepe Üniversitesi Hastanesi Yanık Ünitesi'nde tedavi olmus ve taburcu edilmis, yaralanma sonrası 3-12 ay aralığında rutin kontrole gelen pediatrik yanık hastaları ve anneleri dahil edildi. Çalışmaya dahil edilen pediatrik yanık hastalarının rutin tedavi program içeriğini medikal tedaviler, yara/yanık bakım tedavisi ve gözlem altında veya ev programı şeklinde uygulanan standart yanı rehabilitasyon (egzersiz uygulamaları, ortez ve bası giysisi kullanımı) uygulamaları oluşturmaktadır. Yanık yaralanması olan çocuğun bakımı evde bir bakıcı tarafından gerçekleştiriliyorsa, bu aileler çalışmaya dahil edilmedi. Ayrıca, dış merkezlerden yaralanmanin ilerleyen dönemlerinde rehabilitasyon amacı ile yönlendirilen çocuklar ve anneleri de çalışmaya dahil edilmedi.

Değerlendirmeler

Demografik ve yaniğa özgü değerlendirmeler: Pediatrik yanık hastalarının ve annelerin demografik özellikleri (yaş, boy, vücut ağırlığı, vücut kütle indeksi (VKİ) ve hastaların cinsiyetleri kaydedildi. Annelerin eğitim ve çalışma durumları ile aile tipi sorgulandı. Toplam yanık yüzey alanı (TYYA"Lund ve Browder Grafiği'ne" göre hesaplandı), yanığın oluşma şekli, yanık derinliği, yanık lokalizasyonu, geçirilen cerrahi sayısı, hastanede yatış süresi veya ayaktan tedavi süresi ve yaralanmadan sonra geçen süre kaydedildi. Pediatrik hastaların bası giysisi ve ortez kullanıp kullanmadığı sorgulandı. 
Hipertrofik skar doku değerlendirilmesi: Pediatrik yanık hastalarının skar doku kalitesi Hasta ve Gözlemci Skar Değerlendirme Ölçeği ile değerlendirildi. Ölçek hasta ve gözlemci olmak üzere iki bölümden oluşmaktadır. Hasta ölçeği, yedi parametreyi (renk, esneklik, kalınlık, kabarma, kaşıntı, ağrı, genel düşünce), gözlemci ölçeği ise yedi parametreyi (vaskülarite, pigmentasyon, esneklik, kalınlık ve kabarma, genel düşünce) kapsamaktadır. Tüm maddelerin puanlaması "1=normal cilt" ile "10=en kötü skar görünümü” arasındadır. Yüksek puan skar doku kalitesinin kötüleştiğini gösterir. ${ }^{7-8}$ Ölçeğin Türkçe geçerlik ve güvenirliği Seyyah ve arkadaşları tarafindan yapılmıştır. ${ }^{7}$ Çalışmada uygulanan bu ölçeğin gözlemci kısmı fizyoterapist tarafından, hasta kısmı ise yanık yaralanması olan çocuğun annesi tarafindan dolduruldu.

Eklem hareket açıklı̆̆ de ğerlendirilmesi: Yanık yaralanması olan bölgede yer alan tüm eklemlerin (boyun, omuz, dirsek, el bileği, kalça, diz ve ayak bileği) hareket açıklığı ölçümü gonyometre ile değerlendirildi. ${ }^{9} \mathrm{Bu}$ ölçümler eklemlerin tüm düzlemlerdeki hareketleri (fleksiyon/ekstansiyon, abdüksiyon/addüksiyon, iç/dış rotasyon, pronasyon/supinasyon, inversiyon/eversiyon) için ayrı ayrı tekrarlandı. En az bir düzlemde eklem hareket açıklığında (EHA) kisitlılık varsa, o eklemin EHA'sında limitasyon varlığı olduğu kabul edildi. 10-11

Aileye olan etkinin değerlendirilmesi: Bakım veren kişiler için çocuğun aileye olan yükü Aile Etki Ölçeği ile değerlendirildi. Ölçek sosyo-demografik bilgilerin sorgulandığı ilk bölüm ve anket sorularını içerir. Ölçeğin maddelerinin puanlaması " $1=$ hiç katılmiyorum" ile "4=tamamen katıliyorum" arasındadır. Ölçeğin puanlamasında "Finansal Destek", "Genel Etki", "Sosyal İlişkilerde Bozulma" ve "Başa Çıkma" olmak üzere 4 alt başlık ve "Total Etki" bölümleri hesaplanır. Yüksek puan aileye olan etkinin artığını göstermektedir. ${ }^{12-13}$ Ölçeğin Türkçe geçerlik ve güvenirliği Bek ve arkadaşları tarafından yapılmıştır. ${ }^{13} \mathrm{Bu}$ çalışmada Aileye Etki Ölçeği yanık yaralanması olan çocuğun evdeki bakımını üstlenen anneler tarafindan yanitlandı.

Durumluk-Sürekli Kaygı Ölçeği: Yanık yaralanması olan çocuğa bakım veren annelerin kaygı düzeyleri Durumluk-Sürekli Kaygı Ölçeği ile değerlendirildi. Ölçeğin Türkçe geçerlik ve güvenirliği Öner ve Le Compte tarafından yapılmıştır. ${ }^{14}$ Ölçek 2 ana bölümden oluşmaktadır: Durumluk Kaygı Ölçeği ve Sürekli Kaygı Ölçeği. Ölçeklerin maddeleri "1" ile "4" arasında puanlanır. Her iki ölçeğin toplam puanı 20-80 puan arasinda değişmektedir. Ölçekten alınan yüksek puan, yüksek durumluk/sürekli kaygı düzeyini göstermektedir. ${ }^{14-15}$

İstatistiksel analiz

Veriler IBM İstatistik paket programı versiyon 21 kullanılarak analiz edildi. Tanımlayıcı analizler ortalama (Ort) $\pm_{\text {standart }}$ sapma (SS), yüzde veya oran cinsinden sunuldu. Verilerin normal dağılımları histogram ve Kolmogorov-Smirnov/Shapiro-Wilk testleri kullanılarak analiz edildi. Aile Etki Ölçeği ile sayısal değişkenler (yaş, boy, vücut ağırlığ kardeş sayısı, annenin eğitim düzeyi gibi sosyodemografik veriler, TYYA, cerrahi sayısı, hastanede yatış süresi, yaralanma sonrası geçen süre, Hasta ve Gözlemci Skar Değerlendirme Ölçeği gibi yaralanmaya ilişkin veriler ve Durumluk/Sürekli Kaygı Ölçeği) arasındaki ilişki incelenirken Pearson veya Spearman korelasyon analizi kullanıldı. Aile Etki Ölçeği’nin kategorik değişkenlere göre farklılık gösterip göstermediği, değiş̧en ikili (cinsiyet, pediatrik hastanın okula gitme durumu, annenin üniversite mezunu olma ve çalışma durumu, aile tipi gibi sosyo-demografik veriler, yanık derinliği, yanık lokalizasyonu, tedavi şekli gibi yanığa ilişkin özellikler, hastanın ortez ve bası giysisi kullanma durumu ve hastanın eklemlerindeki limitasyon varlığı gibi klinik değerlendirmeler) ise Mann-Whitney U testi ile değişken üçlü ise (yanığın oluşma şekli) Kruskal-Wallis testi ile analiz edildi. Yapılan analiz testi sonuçlarına göre, Aile Etki Ölçeği ile anlamlı bir ilişki gösterdiği belirlenen sayısal ve kategorik değişkenler çok değişkenli doğrusal regresyon modeline dahil edildi. İstatistiksel olarak anlamlılık düzeyi $\mathrm{p}<0,05$ olarak alındı.

Çalışmanın güç analizi, sonuçlar üzerinde en düşük korelasyon $\left(\mathrm{R}^{2}=0.558\right)$ /etki gösteren sosyal ilişkilerde bozulma faktörü dikkate alınarak hesaplandı. Buna göre yapılan 5 temel etkenli regresyon analizinde etki faktörünün 1,26 olduğu görüldü. 1.26 etki büyüklüğünde, \%5 yanılma düzeyinde 32 katılımcı ile çalışmanın gücü \%99 olarak hesaplandı. Güç analizinde $\mathrm{G}^{*}$ Power Versiyon 3.1.9.6 (Almanya) yazılımı kullanıldı. 


\section{BULGULAR}

Çalışmaya yanık yaralanması olan pediatrik $32(18 \mathrm{~K} / 14 \mathrm{E})$ birey ve anneleri (32) dahil edildi. Pediatrik bireylerin ve annelerinin demografik özellikleri ve yanık yaralanmasına ilişsin tanımlayıcı verileri Tablo 1'de gösterilmiştir. Annelerin klinik değerlendirmelerine ilişkin tanımlayıcı verileri (Aile Etki Ölçeği, Durumluk-Sürekli Kaygı Ölçeği ve Hasta ve Gözlemci Skar Değerlendirme Ölçeği) Tablo 2'de gösterilmiştir.

Aile Etki Ölçeği ile sayısal değişkenler arasındaki korelasyon analiz sonuçlarına göre; Aile Etki Ölçeği total etki puanı ve tüm alt başlık (finansal destek, genel etki, sosyal ilişkilerde bozulma, başa çıkma) puanları ile TYYA, geçirilen cerrahi sayısı, hastanede yatış süresi, yanı yaralanması sonrası geçen süre, Hasta ve Gözlemci Skar Değerlendirme Ölçeği puanları ve Durumluk-Sürekli Kaygı Ölçeği puanları arasında pozitif yönde istatistiksel olarak anlamlı bir ilişki bulundu $(\mathrm{p}<0,05)$. Aile Etki Ölçeği puanları ile demografik veriler arasındaki korelasyon analizi incelendiğinde, Aile Etki Ölçeği total etki ve genel etki puanı ile çocuğun yaşı, boyu, kardeş sayısı, annenin yaşı arasında, Aile Etki Ölçeği finansal destek puanı ile çocuğun demografik bilgileri (yaş, boy, vücut ağırlığı), kardeş sayısı, annenin demografik bilgileri (yaş, vücut ağırlığı, VKİ) arasında pozitif yönde istatistiksel olarak anlamlı bir ilişki olduğu saptandı $(p<0,05)$.

Aile Etki Ölçeği ile değerlendirilen aile yükünün kategorik değişkenlere göre farklılık gösterip göstermediğini analiz etmek için yapılan ikili/üçlü karşılaştırma sonuçlarına göre, pediatrik hastanın kardeşinin olduğu ailelerde olmayanlara göre total etki ve finansal destek yükünün daha yüksek olduğu bulundu $(\mathrm{p}<0,05)$. Annenin üniversite mezunu olduğu ailelerde olmayanlara göre finansal destek yükünün daha düşük olduğu görüldü $(p<0,05)$. Annenin bir işte çalıştığ çalışmayanlara göre total etki, sosyal ilişkilerde bozulma ve finansal destek açısından aile yükünün daha düşük olduğu görüldü $(p<0,05)$. Alev yanıklarında haşlanma ve temas yanıklarına göre total etki, genel etki, finansal destek ve sosyal ilişkilerde bozulma açısından aile yükünün daha yüksek olduğu bulundu $(p<0,05)$. Çocuğun yanık derecesinin daha fazla olduğu ailelerde finansal yükün daha yüksek olduğu belirlendi $(p<0,05)$. Yüz ve boyun bölgesinde, alt ekstremitelerinde yanık yaralanması olan çocukların ailelerinde olmayanlara göre total etki, genel etki, sosyal ilişkilerde bozulma ve finansal destek açısından aile yükünün daha yüksek olduğu görüldü $(p<0,05)$. Ayak bölgesinde yanığı olan çocukların ailelerinde olmayanlara göre finansal yükün daha yüksek olduğu bulundu $(\mathrm{p}<0,05)$. Herhangi bir ekleminde, üst ekstremite eklemlerinde, dirsek ekleminde, alt ekstremite eklemlerinde veya ayak bileği ekleminde limitasyon olan çocukların ailelerinde limitasyon olmayanlara göre tüm alt ölçekler ve total etki açısından aile yükünün daha yüksek olduğu bulundu $(p<0,05)$. El/el bileği ekleminde limitasyon olan pediatrik hastalarm ailerinde genel etki, sosyal ilişkilerde bozulma ve total etki, omuz ekleminde limitasyon olan çocukların ailelerinde ise total etki, genel etki, finansal destek ve başa çıkma, diz ekleminde limitasyon olan çocukların ailelerinde ise total etki ve sosyal ilişkiler bozulma puanları açısından limitasyon bulunmayan çocukların ailelerine göre aile yükünün daha fazla olduğu belirlendi $(\mathrm{p}<0,05)$. Cerrahi geçmişi olan, yatarak tedavi edilen ve taburculuk sonrası bası giysisi kullanan çocukların ailelerinde tüm alt ölçekler ve total etki açısından aile yükünün daha yüksek olduğu bulundu $(\mathrm{p}<0,05)$.

Aile Etki Ölçeği'ni etkileyen faktörlerin çoklu doğrusal regresyon analiz sonuçlarına göre, daha yüksek kaygı düzeyinin, çocukların bası giysisi kullanmasının, kötüleşmiş skar doku kalitesinin (Hasta ve Gözlemci Skar Değerlendirme Ölçeği-hasta puanı) ve yanık sonrası geçen süredeki artışın total etki açısından aile yükünü artırdığı bulundu $\left(p<0,05, \quad R^{2}=0,856\right.$, Tablo 3). Daha yüksek TYYA'nın, çocuğun herhangi bir ekleminde limitasyon varlığının ve cerrahi sayısındaki artışın ise Aile Etki Ölçeği finansal destek açısından aile yükünü artırdığı belirlendi $\left(\mathrm{p}<0,05, \mathrm{R}^{2}=0,872\right.$, Tablo 3$)$. Kötüleşmiş skar doku kalitesinin (Hasta ve Gözlemci Skar Değerlendirme Ölçeği-hasta puanı), çocuğun herhangi bir ekleminde limitasyon bulunmasının ve yanık sonrası geçen süredeki artışın Aile Etki Ölçeği genel etki açısından aile yükünü artırdığı görüldü $\left(p<0,05, \quad R^{2}=0,801\right.$, Tablo 3). Annelerin daha yüksek kaygı düzeyinin ve çocuğun üst ekstremite 
eklemlerinde limitasyon varlığının Aile Etki Ölçeği sosyal ilişkilerde bozulma açısından $\left(\mathrm{R}^{2}=0,558\right)$, kötüleşmiş skar doku kalitesinin (Hasta ve Gözlemci Skar Değerlendirme Ölçeğihasta puanı $\quad\left(\mathrm{R}^{2}=0,607\right)$ ise başa çıkma açısından aile yükünü artırdığı bulundu $(\mathrm{p}<0,05$, Tablo 3$)$.

\section{TARTIŞMA}

Çalışmamızın sonuçları incelendiğinde, annelerin yüksek kaygı düzeyine sahip olmasının, çocuğun tedavi sürecinde bası giysisi kullanmasının, kötüleşmiş skar doku kalitesinin ve yaralanmadan sonra geçen süredeki artışı çocuğun aileye olan yükünü artırdığ gösterildi. Pediatrik yanık hastasında limitasyon varlığının, artmış TYYA ile cerrahi sayısının ise aileye olan finansal yükü artırdığı belirlendi. Ayrica, eklemlerde limitasyon varlığının, kötüleşmiş skar doku kalitesinin ve yaralanmadan sonra geçen süredeki artışın Aile Etki Ölçeği genel etki puanını artırdığı ve aileye olan yükü olumsuz yönde etkilediği tespit edildi. Buna ek olarak, annelerin yüksek sürekli kaygı düzeyine sahip olmasının ve pediatrik yanıklarda üst ekstremite eklemlerinde limitasyon varlığının ailenin sosyal ilişkilerinde bozulmaya yol açtığ doku kalitesinin ise, ailenin yükünü artırmasına ek olarak ailenin bu olayla başa çıkma durumunu da olumsuz yönde etkilediği gösterildi.

Literatürde, serebral palsi, nöromusküler hastalıklar, kistik fibrozis ve obstetrik brakial pleksus gibi kronik çocukluk çağı hastalıklarında yapılan araştırmalarda çocuğun kronik hastalığa sahip olmasının aileler üzerinde olumsuz etkisinin olduğu gösterilmiştir.16-19 Pediatrik yanıklarda annelerin kaygi ve depresyon düzeylerini araştıran çalışmaların sonuçları da birbiri ile benzerlik göstermektedir. ${ }^{2-5}$ Egberts vd. yaptıkları araştırmada yanık yaralanmasını takiben 1., 12. ve 18. aylarda annelerin duygu durumlarını değerlendirmişlerdir. ${ }^{5}$ Sonuç olarak, yaralanma sonrası erken dönemde yüksek düzeyde korku, kaygı, üzüntü ve suçluluk gibi duyguların ilerleyen dönemlerde uzamış posttravmatik stres ve depresyon semptomları ile ilişkili olduğunu göstermişlerdir. ${ }^{5}$ Durumluk ve sürekli kaygı ölçeği için kesme değerinin 39-40 olduğu göz önünde bulundurulduğunda, mevcut çalışmada annelerin büyük çoğunluğunun (\%96) yüksek kaygı düzeyine sahip olduğu belirlendi. ${ }^{15}$ Buna ek olarak, annelerin kaygı düzeyindeki artışın, yanık yaralanmasının aileye olan yükünü olumsuz yönde etkilediği gösterildi. Yanık yaralanması sonrası oluşan fonksiyonel kayiplar uzayan tedavi süreçleri ile birleştiğinde sadece yanık yaralanması olan çocuk değil, çocuğun bakım ve rehabilitasyon süreçlerinde önemli bir rol üstlenen anne ve aile yaşamı da tümüyle etkilenmektedir. ${ }^{3}$ Yanık tedavisinin yıllara yayılan uzun bir süreç olduğu düşünüldüğünde, çalışmamızda yanık yaralanması sonrası geçen süre arttıkça aile yükünün de total ve genel etki açısından artması beklenen bir sonuçtu. Yanık yaralanmasını takiben oluşan en önemli komplikasyonlardan birisi hipertrofik skardır. ${ }^{20}$ Görülebilir yerlerdeki skarlar annenin kaygı düzeyini artıran etmenlerin başında gelmektedir. ${ }^{3,5}$ Hipertrofik skar tedavisinde altın standart kabul edilen bası giysisi kullanımına alışma, çocuğun bakımını üstlenen anne için yeni ve zorlayıcı bir süreç olabilmektedir. ${ }^{3} \quad$ Hipertrofik skar tedavisi sürecinde duygusal zorluklarla başa çıkabilmeyi öğrenebilen ailelerin, bakım veren rollerinde daha başarılı oldukları gösterilmiştir. ${ }^{3}$ Çalışmamızda ise, pediatrik yanıklarda kötüleşmiş skar doku kalitesi annenin kaygı düzeyini artırarak hem aile yükünü (Aile Etki Ölçeği total ve genel etki puanı) hem de ailenin bu durumla başa çıkabilme yeteneğini olumsuz yönde etkilemiş olabilir. Buna ek olarak, hipertrofik skar tedavisinde kullanılan bası giysilerinin maliyetli olması ve takip sıklığ gerektirmesi, yanığin aileye olan yükünü artırmış olabileceği görüşündeyiz.

Çalışmamızın sonuçlarına göre, pediatrik yanıklarda TYYA ve cerrahi sayısındaki artışın aileler için finansal bir yük oluşturduğunu ve herhangi bir eklemdeki limitasyonun hem finansal yük oluşturduğunu hem de aile yükü genel etkisini artırdığı belirlendi. TYYA yanığın şiddetini belirleyen ve uzun dönem komplikasyonlardan biri olan hipertrofik skar oluşumuna yol açan belirteçlerden biridir.. ${ }^{21}$ TYYA'ndaki artış hastanede yatış süresinin uzamasina ve cerrahi gereksinimine yol açabilir. ${ }^{22}$ Özellikle eklemi içine alan yanıklarda ilerleyen süreçlerde oluşabilecek limitasyonu 
Tablo 1. Katılımcıların demografik özellikleri ve yanık değerlendirmelerine ilişkin tanımlayıcı verileri.

\begin{tabular}{|c|c|c|c|}
\hline \multicolumn{4}{|l|}{ Demografik özellikler } \\
\hline \multirow[t]{14}{*}{ Pediatrik yanık hastaları $(\mathrm{N}=32)$} & \multicolumn{2}{|l|}{ Cinsiyet (Kadın/Erkek) (n (\%)) } & $18 / 14(56 / 44)$ \\
\hline & Yaş (yıl) $(X \pm S D)$ & & $8,12 \pm 4,24$ \\
\hline & \multirow[t]{4}{*}{ Yaş dağılımı n (\%) } & $0-5$ yaş & $14(43,8)$ \\
\hline & & $6-10$ yaş & $8(25)$ \\
\hline & & $10-15$ yaş & $8(25)$ \\
\hline & & 15 yaş ve üzeri & $2(6,2)$ \\
\hline & \multicolumn{2}{|l|}{ Boy $(\mathrm{cm})(X \pm S D)$} & $113,75 \pm 22,83$ \\
\hline & \multicolumn{2}{|c|}{ Vücut ağırlığı $(\mathrm{kg})(X \pm S D)$} & $26,09 \pm 12,48$ \\
\hline & \multicolumn{2}{|c|}{ Vücut kütle indeksi $\left(\mathrm{kg} / \mathrm{m}^{2}\right)(\mathrm{X} \pm \mathrm{SD})$} & $19,03 \pm 2,35$ \\
\hline & \multicolumn{2}{|c|}{ Okula devam eden kişi sayısı n (\%) } & $15(\% 46,9)$ \\
\hline & Kardeş sayısı n (\%) & 0 & $10(31,3)$ \\
\hline & & 1 & $15(46,9)$ \\
\hline & & 2 & $6(18,8)$ \\
\hline & & 3 & $1(3,1)$ \\
\hline \multirow[t]{11}{*}{ Anneler $(\mathrm{N}=32)$} & \multicolumn{2}{|l|}{ Yaş (yıl) $(X \pm S D)$} & $38,43 \pm 7,53$ \\
\hline & \multicolumn{2}{|l|}{ Boy $(\mathrm{cm})(\mathrm{X} \pm \mathrm{SD})$} & $162,18 \pm 2,76$ \\
\hline & \multicolumn{2}{|l|}{ Vücut ağırlığı (kg) (X士SD) } & $60,93 \pm 4,68$ \\
\hline & \multicolumn{2}{|c|}{ Vücut kütle indeksi $\left(\mathrm{kg} / \mathrm{m}^{2}\right)(\mathrm{X} \pm \mathrm{SD})$} & $23,16 \pm 1,76$ \\
\hline & \multicolumn{2}{|c|}{ Eğitim düzeyi (yıl) $(\mathrm{X} \pm \mathrm{SD})$} & $10,18 \pm 3,09$ \\
\hline & Üniversite mezun durumu & Mezun & $4(12,5)$ \\
\hline & $\mathrm{n}(\%)$ & Mezun değil & $28(87,5)$ \\
\hline & Çalışma durumu $n$ (\%) & Çalışıyor & $13(40,6)$ \\
\hline & & Çalışmıyor & $19(59,4)$ \\
\hline & Medeni durumu n (\%) & Evli & $31(96,9)$ \\
\hline & & Bekar & $1(3,1)$ \\
\hline \multicolumn{4}{|l|}{ Yanığa özgü ve klinik değerlendirmeleri } \\
\hline Toplam yanık yüzey alanı (\%) $(\mathrm{X} \pm$ SD) & \multirow{2}{*}{\multicolumn{2}{|c|}{ Haşlanma }} & $13,31 \pm 11,71$ \\
\hline \multirow[t]{3}{*}{ Yanığın oluşma şekli n (\%) } & & & $20(62,5)$ \\
\hline & Temas & & $8(25)$ \\
\hline & Alev & & $4(12,5)$ \\
\hline Yanık derinliği n (\%) & 2. derece derin ve yüzeyel & & $5(15,6)$ \\
\hline & 2. derece derin ve 3 . derece & & $27(84,4)$ \\
\hline Yanık lokalizasyonu (bölgelere göre yanık varlığı & Yüz ve boyun & & $8(25)$ \\
\hline durumu) $n(\%)$ & Gövde & & $8(25)$ \\
\hline & Üst Ekstremite & & $26(81,3)$ \\
\hline & $\mathrm{El}$ & & $22(68,8)$ \\
\hline & Alt Ekstremite & & $10(31,3)$ \\
\hline & Ayak & & $8(25)$ \\
\hline Cerrahi sayısı n (\%) & 0 & & $15(46,9)$ \\
\hline & 1 & & $10(31,3)$ \\
\hline & 2 & & $3(9,4)$ \\
\hline & 3 & & $4(12,5)$ \\
\hline Takip şekli n (\%) & Yatarak Tedavi & & $21(65,6)$ \\
\hline & Ayaktan Tedavi & & $11(34,4)$ \\
\hline Standart yanık rehabilitasyonu uygulama şekli n (\%) & Gözlem altında & & $10(31,25)$ \\
\hline & Ev programı & & $22(68,75)$ \\
\hline Hastanede yatış süresi veya ayaktan tedavi süresi (gü & $(X \pm S D)$ & & $30,5 \pm 33,81$ \\
\hline Yanık yaralanması sonrası geçen süre (ay) & & & $5,5 \pm 2,14$ \\
\hline Bası giysisi kullanan hasta sayısı n (\%) & & & $9(28,1)$ \\
\hline Ortez kullanan hasta sayısı n (\%) & & & $18(56,3)$ \\
\hline Herhangi bir eklemde limitasyon olan hasta sayısı n ( & & & $15(46,9)$ \\
\hline Birden fazla üst ekstremite ekleminde limitasyon ola & hasta sayısı n (\%) & & $11(34,4)$ \\
\hline El bileği ekleminde limitasyon olan hasta sayısı $n(\%)$ & & & $7(21,9)$ \\
\hline Dirsek ekleminde limitasyon olan hasta sayısı n (\%) & & & $4(12,5)$ \\
\hline Omuz ekleminde limitasyon olan hasta sayısı $n(\%)$ & & & $2(6,3)$ \\
\hline Alt ekstremite eklemlerinde limitasyon olan hasta sa & $\sin (\%)$ & & $8(25)$ \\
\hline Ayak bileği ekleminde limitasyon olan hasta sayısı $\mathrm{n}$ & & & $8(25)$ \\
\hline Diz ekleminde limitasyon olan hasta sayısı $n$ (\%) & & & $2(6,3)$ \\
\hline Kalça ekleminde limitasyon olan hasta sayısı n (\%) & & & $1(3,1)$ \\
\hline
\end{tabular}


Tablo 2. Annelerin değerlendirmelerine ilişkin tanımlayıcı veriler.

\begin{tabular}{lc}
\hline & $X \pm S D$ \\
\hline Aile Etki Ölçeği & $61,71 \pm 17,47$ \\
Total Etki & $9,43 \pm 3,62$ \\
Finansal Destek & $22,25 \pm 7,87$ \\
Genel Etki & $16,68 \pm 4,43$ \\
Sosyal İlişkilerde Bozulma & $13,34 \pm 3,66$ \\
$\quad$ Başa Çıma & \\
Hasta ve Gözlemci Skar Değerlendirme Ölçeği & $55,09 \pm 6,44$ \\
$\quad$ Hasta & $56,90 \pm 6,47$ \\
Gözlemci & \\
Durumluk-Sürekli Kaygı Ölçeği & $55,53 \pm 9,10$ \\
$\quad$ Durumluk Kayğ Ölçeği & $57,53 \pm 9,43$ \\
Sürekli Kaygı Ölçeği &
\end{tabular}

Tablo 3. Pediatrik yanık hastalarında Aile Etki Ölçeğini etkileyen faktörlerin çoklu doğrusal regresyon analiz sonuçları.

\begin{tabular}{|c|c|c|c|c|c|}
\hline & B & $\begin{array}{l}\% 95 \mathrm{GA} \\
\text { Alt Sinır }\end{array}$ & Üst sınır & p & $\mathbf{R}^{2}$ \\
\hline \multicolumn{6}{|l|}{ Total Etki } \\
\hline Sürekli Kaygı Ölçeği & 0,696 & 0,264 & 1,128 & $0,003 *$ & \multirow{4}{*}{0,856} \\
\hline Bası giysisi varlığı & 9,684 & 2,004 & 17,364 & $0,015^{*}$ & \\
\hline Hasta ve Gözlemci Skar Değerlendirme Ölçeği (Hasta puanı) & 0,969 & 0,348 & 1,591 & $0,003 *$ & \\
\hline Yanık yaralanması sonrası geçen süre & 1,715 & 0,103 & 3,327 & $0,038 *$ & \\
\hline \multicolumn{6}{|l|}{ Finansal Destek } \\
\hline Toplam yanık yüzey alanı & 0,093 & 0,007 & 0,179 & $0,036 *$ & \multirow{3}{*}{0,872} \\
\hline Limitasyon varlığı & 3,282 & 1,950 & 4,614 & $<0,001$ & \\
\hline Cerrahi sayısı & 1,007 & 0,098 & 1,917 & $0,031 *$ & \\
\hline \multicolumn{6}{|l|}{ Genel Etki } \\
\hline Hasta ve Gözlemci Skar Değerlendirme Ölçeği (Hasta puanı) & 0,702 & 0,469 & 0,935 & $<0,001$ & \multirow{3}{*}{0,801} \\
\hline Yanık yaralanması sonrası geçen süre & 1,165 & 0,447 & 1,884 & $0,002 *$ & \\
\hline Limitasyon varlığı & 4,177 & 0,941 & 7,413 & $0,013 *$ & \\
\hline \multicolumn{6}{|l|}{ Sosyal İlişkilerde Bozulma } \\
\hline Sürekli Kaygı Ölçeği & 0,237 & 0,105 & 0,368 & $0,001 *$ & \multirow{2}{*}{0,558} \\
\hline Üst ekstremitede limitasyon varlığı & 3,460 & 0,882 & 6,037 & $0,010 *$ & \\
\hline \multicolumn{6}{|l|}{ Başa Çıkma } \\
\hline Hasta ve Gözlemci Skar Değerlendirme Ölçeği (Hasta puanı) & 0,444 & 0,311 & 0,577 & $<0,001$ & 0,607 \\
\hline
\end{tabular}

önlemek için erken dönemde cerrahi yapılması koruyucu rehabilitasyon açısından büyük önem taşır. ${ }^{22}$ Ancak pediatrik yanıklarda, çocuğun motor gelişimi ile paralel olarak cerrahilerin belirli zaman aralıkları ile tekrarlanması gerekebilir. $^{23} \mathrm{Bu}$ sebeple, her bir cerrahi yeniden hastaneye yatışa veya hastanede yatış süresinin uzamasina neden olabilmektedir. ${ }^{22-23}$ Ayrıca, pediatrik yanıklarda ilerleyen süreçlerde cerrahi gerektirebilen en önemli komplikasyonlardan birisi olan eklem limitasyonları tedavisinde cerrahi öncesi ve sonrası yoğunlaştırılmış rehabilitasyon programının uygulanması cerrahinin başarısı için de bir önkoşuldur. ${ }^{23-25}$ Yüz yüze veya uzaktan rehabilitasyon süreci, annenin aktif bir bakım veren rolü üstlenmesini gerektirir. ${ }^{3}$ Çalışmamızda, pediatrik yanık hastasındaki eklem limitasyonları annenin tedavi sürecindeki yükünü artırarak yanığın aileye olan genel etkisini olumsuz yönde etkilemiş olabilir. Buna ek olarak, artmış TYYA ve cerrahi 
sayısı ile limitasyon varlığı yanık yaralanması olan çocuğun hastanedeki yanık tedavi sürecinin uzamasına yol açarak ailenin finansal yükünü artırmış olabilir.

Çalışmamızda, annenin yüksek kaygı düzeyine sahip olmasının ve çocuğun herhangi bir üst ekstremite ekleminde limitasyon bulunmasının ailenin sosyal ilişkilerini olumsuz yönde etkilediği gösterildi. Üst ekstremite fonksiyonu çocuğun sosyal ortamlarda aktivite ve katılımı için büyük önem taşır. ${ }^{26} \mathrm{Bu}$ yüzden üst ekstremite eklemlerindeki limitasyon çocuğun fonksiyonelliğini etkileyerek aktivite ve katılımını kısıtlayabilir. ${ }^{26}$ Üst ekstremite yanık rehabilitasyonunda ortez ve bası giysisi kullanımı ile birlikte fonksiyonelliğin geri kazanılması için cerrahiye de sıklıkla ihtiyaç duyulmaktadır. ${ }^{23-25}$ Cerrahi öncesi ve sonrası fonksiyonu koruyucu amaçlı üst ekstremite yanık rehabilitasyonunda hipertrofik skarda olduğu gibi anne, bakım veren olarak önemli bir rol üstlenir. ${ }^{3}$ Anneler bu uzayan tedavi sürecinde, üst ekstremite fonksiyonlarının tamamen geri kazanılması veya ilerleyen süreçlerde çocuklarının yaşıtları ile benzer motor gelişime ulaşabilmesi gibi konularda kaygı duyabilmektedir. ${ }^{3}$ Çalışmamızda da geniş kapsamlı tedavi süreçlerinden geçmiş pediatrik yanıklarda annelerin artmış kaygı düzeyi ve üst ekstremite limitasyonları ailenin sosyal hayatı için bir bariyer oluşturmuş olabilir.

Limitasyonlar

$\mathrm{Bu}$ çalışmanın en önemli limitasyonu çalışmaya dahil edilen çocukların büyük çoğunluğunun küçük ve orta şiddetli (TYYA<\%10) yaralanmaya sahip olmasıdır. Bu nedenle, sonuçları tüm pediatrik yaralanması olan çocukların ailelerine genellemek mümkün değildir. Yanık sonrası geçen sürenin etkisi istatistiksel analiz ile yorumlanmış olsa da, bireylerin yaralanma sonrası 3-12 aylık geniş bir zaman dilimi içerisinde değerlendirilmiş olması bir diğer limitasyon olabilir. Değerlendirilme zamanının önemi göz önünde bulundurulduğunda, yanığın aileye olan etkisinin prospektif olarak, yaralanma sonrası 3., 6. ve 12 . ay gibi uzun süreli takiplerle araştırıldığı çalışmalara ihtiyaç duyulmaktadır.

\section{Sonuç}

Sonuç olarak, annenin yüksek kaygı düzeyine sahip olması, kötüleşmiş skar doku kalitesi, bası giysisi kullanımı, yaralanma sonrası geçen süredeki artış, herhangi bir eklemde veya üst ekstremitede limitasyon varlığı, artmış TYYA ve cerrahi sayısı yanığın aileye olan yükünü artıran parametrelerdir. Yanık yaralanması olan çocuklarda tedavi planlanmasında, çocuk ve ailenin bütüncül olarak değerlendirilmesi, çocuk ve anne/bakım veren odaklı rehabilitasyon programı önerilir

\section{Teşekkür: Yok.}

Yazarların Katkı Beyanı: ÖÖ: Fikir gelişimi, çalışma dizayn, veri toplama, veri analizi, literatür araştırma, yazma; DAÖ: Çalışma dizaynı, veri toplama, veri analizi, literatür araştırma, yazma; GA: Çalışma dizaynı, veri toplama, veri analizi, literatür araştırma, yazma; ST: Çalışma dizaynı, proje yönetimi, literatür araştırması, veri analizi, kritik gözden geçirme; AK: Çalışma dizaynı, proje yönetimi, olguların sağlanması, veri analizi, kritik gözden geçirme.

Çıkar Çatışması: Yok.

Finans: Yok.

Etik Onay: $\mathrm{Bu}$ araştırma protokolü Hacettepe Üniversitesi Girişimsel Olmayan Klinik Araştırmalar Etik Kurulu (say1: GO 19/28, tarih: 08.01.2019) tarafindan onaylandı.

\section{KAYNAKLAR}

1. Sveen J, Sjöberg F, Öster C. Health-related quality of life in Swedish pediatric burn patients and associations with burn and family characteristics. Burns. 2014;40:987-994.

2. McGarry S, Girdler S, McDonald A, et al. Paediatric medical trauma: The impact on parents of burn survivors. Burns. 2013;39:11141121.

3. Andrews N, Jones LL, Moiemen N, et al. Below the surface: Parents' views on the factors that influence treatment adherence in paediatric burn scar management - A qualitative study. Burns. 2018;44:626-635.

4. Brown EA, De Young A, Kimble R, et al. Impact of Parental Acute Psychological Distress on Young Child Pain-Related Behavior Through Differences in Parenting Behavior During Pediatric Burn Wound Care. J Clin Psychol Med Settings. 2019;26:516-529.

5. Egberts MR, Engelhard IM, Schoot RV, et al. Mothers' emotions after pediatric burn injury: Longitudinal associations with posttraumatic 
stress and depressive symptoms 18 months postburn. J Affect Disord. 2020;263:463-471.

6. Johnson RM, Richard R. Partial-thickness burns: identification and management. Adv Skin Wound Care. 2003;16:178-187.

7. Seyyah M, Yurdalan SU. Cultural adaptation and validation of patient and observer scar assessment scale for Turkish use. Burns. 2018;44:1352-1356.

8. Draaijers LJ, Tempelman FR, Botman YA, et al. The patient and observer scar assessment scale: a reliable and feasible tool for scar evaluation. Plast Reconstr Surg. 2004;113:1960-1967.

9. Norkin CC, White DJ. Measurement of Joint Motion: A Guide to Goniometry. Philadelphia: F.A. Davis Company; 2003.

10. Özkal Ö, Seyyah M, Topuz S, et al. Lower limb functional status and its determinants in moderate/major burns 3-6 months following injury: A two-center observational study. Burns. 47:676-683.

11. Lensing J, Wibbenmeyer L, Liao J, et al. Demographic and Burn Injury-Specific Variables Associated with Limited Joint Mobility at Discharge in a Multicenter Study. Burn Care Res. 2020;41:363-370.

12. Stein RE, Jessop DJ. The impact on family scale revisited: further psychometric data. J Dev Behav Pediatr. 2003;24:9-16.

13. Bek N, Simsek IE, Erel S, et al. Turkish version of impact on family scale: a study of reliability and validity. Health Qual Life Outcomes. 2009;7:4-7.

14. Öner N, Le Compte A. Durumluk-sürekli kayg1 envanteri el kitabı. Boğaziçi Üniversitesi Yayınları, İstanbul; 1985.

15. Spielberger CD, Gorsuch RL, Lushene R, Vagg PR, Jacobs GA. Manual for the State-Trait Anxiety Inventory. Palo Alto/CA: Consulting Psychologists Press; 1983.
16. Çankaya Ö, Kerem-Günel M. Okul çağı serebral palsili çocuklarda kişisel faktörler, günlük aktivite performansı ve aileye olan etkinin karşılaştırılması. J Exerc Ther Rehabil. 2020;7:213-220.

17. Firat T, Oskay D, Akel BS, et al. Impact of obstetrical brachial plexus injury on parents. Pediatr Int. 2012;54:881-884.

18. Yılmaz O, Yıldırım SA, Öksüz Ç, et al. Mothers' depression and health-related quality of life in neuromuscular diseases: role of functional independence level of the children. Pediatr. Int. 2010;52:648-652.

19. Vardar-Yağlı N, Sağlam M, Inal-İnce D, et al. Hospitalization of children with cystic fibrosis adversely affects mothers' physical activity, sleep quality, and psychological status. J Child Fam Stud. 2017:26;800-809.

20. Kidd LR, Nguyen DQ, Lyons SC, et al. Following up the follow up - long-term complications in paediatric burns. Burns. 2013;39:55-60.

21. van der Wal MB, Vloemans JF, Tuinebreijer WE, et al. Outcome after burns: an observational study on burn scar maturation and predictors for severe scarring. Wound Repair Regen. 2012;20:676-687.

22. Spanholtz TA, Theodorou P, Amini P, et al. Severe burn injuries: acute and long-term treatment. Dtsch Arztebl Int. 2009;106:607-613.

23. Krishnamoorthy V, Ramaiah R, Bhananker SM. Pediatric burn injuries. Int J Crit Illn Inj Sci. 2012;2:128-134.

24. Shah AR, Liao LF. Pediatric Burn Care: Unique Considerations in Management. Clin Plast Surg. 2017;44:603-610.

25. Young AW, Dewey WS, King BT. Rehabilitation of Burn Injuries: An Update. Phys Med Rehabil Clin N Am. 2019;30:111-132.

26. Lozano E, Potterton J. The use of xbox kinectTM in a pediatric burns unit. South Afr J Physiother. 2018;74:1-7. 